\title{
Erratum to: The dominance of the private sector in the provision of emergency obstetric care: studies from Gujarat, India
}

Mariano Salazar ${ }^{1 *}$, Kranti Vora ${ }^{2}$ and Ayesha De Costa ${ }^{1,2}$

\section{Erratum}

Following the publication of this article [1] it was brought to our attention that two values in Table 4 were incorrect:

1. In the Sabarkantha district, under the Deficit column, number 73 should read 37.

2. In the Dahod district, under the Deficit column, number 12 should read 13 .

\section{Author details}

'Department of Public Health Sciences, Karolinska Institutet

Tomtebodavägen 18a, Widerströmska Huset, 17177 Stockholm, Sweden. ${ }^{2}$ Department of Reproductive and Child Health, Indian Institute of Public

Health, Gandhinagar, Ahmedabad, Gujarat, India.

Published online: 09 August 2016

\section{References}

1. Salazar $\mathrm{M}$, et al. The dominance of the private sector in the provision of emergency obstetric care: studies from Gujarat, India. BMC Health Serv Res. 2016;16:225. doi:10.1186/s12913-016-1473-8.

\footnotetext{
* Correspondence: mariano.salazar@ki.se

'Department of Public Health Sciences, Karolinska Institutet,

Tomtebodavägen 18a, Widerströmska Huset, 17177 Stockholm, Sweden

Full list of author information is available at the end of the article
}

Submit your next manuscript to BioMed Central and we will help you at every step:

- We accept pre-submission inquiries

- Our selector tool helps you to find the most relevant journal

- We provide round the clock customer support

- Convenient online submission

- Thorough peer review

- Inclusion in PubMed and all major indexing services

- Maximum visibility for your research

Submit your manuscript at

www.biomedcentral.com/submit 
Table 4 Staff and facilities per district compared against WHR 2005 benchmarks ${ }^{a}$

\begin{tabular}{|c|c|c|c|c|c|c|c|c|c|}
\hline \multirow[t]{4}{*}{ Indicator } & \multicolumn{9}{|c|}{ Districts and number of births per year } \\
\hline & \multirow{2}{*}{\multicolumn{3}{|c|}{$\begin{array}{l}\text { Sabarkantha (births: } 67,965) \\
\text { Number of facilities or staff }\end{array}$}} & \multirow{2}{*}{\multicolumn{3}{|c|}{$\begin{array}{l}\text { Dahod (births: } 64,222 \text { ) } \\
\text { Number of facilities or staff }\end{array}$}} & \multirow{2}{*}{\multicolumn{3}{|c|}{$\begin{array}{l}\text { Surendranaga (births: } 67,965 \text { ) } \\
\text { Number of facilities or staff }\end{array}$}} \\
\hline & & & & & & & & & \\
\hline & Current & WHR 2005 & Deficit & Current & WHR 2005 & Deficit & Current & WHR 2005 & Deficit \\
\hline CEmOC & 15 & 19 & 4 & 5 & 18 & 13 & 3 & 11 & 8 \\
\hline BEmOC & 1 & 38 & 37 & 0 & 36 & 36 & 2 & 22 & 20 \\
\hline Less-than-BEmOC $+C$-sections & 41 & n.a & n.a & 12 & n.a & n.a & 19 & n.a & n.a \\
\hline Midwives (nurses) ${ }^{\mathrm{b}}$ & 103 & 378 & 275 & 98 & 357 & 259 & 51 & 224 & 173 \\
\hline Doctors (all) & 126 & 57 & 0 & 55 & 54 & 1 & 59 & 34 & 0 \\
\hline
\end{tabular}

aWHR 2005 benchmarks recommend the following: a. 20 midwifes and three part-time doctors per 3600 births and b. one CEmOC facility and one to two BEmOC

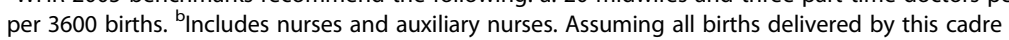

